\title{
Polymorphism Gene GH and Morphological Characteristic of Anas platyrhynchos and Cairina moschata
}

\author{
Firman Febrianto, Ismoyowati, Mochamad Mufti, Prayitno and Dattadewi Purwantini \\ Faculty of Animal Science, Jenderal Soedirman University, Purwokerto, Indonesia \\ *Corresponding author email: moy.moyowati@gmail.com
}

\begin{abstract}
The aims of this research was to identify the qualitative and quantitative difference of the phenotypes, as well as genetic differences based on the polymorphism of gene growth hormone (GH) of mallard and Muscovy ducks. The materials were 30-week old male and female ducks from 5 strains-Magelang, Mojosari and Tegal ducks, white-feathered, and black and white-feathered Muscovy ducks. The research design used was a completely randomized design (CRD) with 5 different lines based on sex with 5 replications. The variables measured included quantitative and qualitative characteristics, heterozygosity and genetic distance. Qualitative characteristics were analyzed descriptively, and quantitative characteristics were analyzed using Anova followed by HSD in case of significant differences. RFLP analysis was used to determine the allele frequencies, genotype frequencies, genetic diversity, and genetic distance of local ducks. Result showed phenotypic differences between Anas platyrhynchos and Cairina moschata. The results showed that there were differences in the phenotypes Anas platyrhynchos and Cairina moschata. Muscovy ducks's feather color was dominant black and white, while the mallard appeared brown. The bill color Muscovy duck was pink with dark brown, but black in the mallard. The dominant shank's color in both Muscovy and mallard was black. Body size of Muscovy duck was larger than a mallard. The body weight of Magelang duck was higher than Tegal and Mojosari Duck. The result of PCR-RFLP showed that mallard had lower heterozygosity than Muscovy duck, based on GH gene. The genetic distance of Tegal Ducks was close to Mojosari and Magelang ducks, while Magelang and Mojosari Ducks had considerable genetic distance based on the GH gene.
\end{abstract}

Keywords: mallard, Muscovy, GH Anas, GH Cairina, PCR-RFLP.

Abstrak. Penelitian ini bertujuan untuk mempelajari perbedaan fenotipik itik lokal dan entok secara kualitatif dan kuantitatif, serta perbedaan genetik berdasarkan polimorfime gen growth hormon (GH). Materi yang digunakan adalah Itik Magelang, Mojosari, Tegal, Entok Bulu Putih, dan Entok bulu kombinasi hitam-putih jantan dan betina umur 30 minggu. Rancangan penelitian yang digunakan adalah Rancangan Acak Lengkap (RAL) dengan faktor pembeda 5 galur itik bedasarkan jenis kelamin dan ulangan 5 kali. Peubah yang diukur meliputi karakteristik kuantitatif dan kualitatif, heterozigositas serta jarak genetik. Sifat kualitatif dianalisis secara deskriptif, dan sifat kuantitatif dianalisis menggunakan analisis variansi dengan uji lanjut Beda Nyata Jujur (BNJ). Perbedaan genetik berdasarkan polimorfisme gen GH dianalisis dengan menghitung frequensi alel, frequensi genotip, heterozigositas, dan jarak genetik Itik Lokal. Hasil penelitian menunjukkan bahwa terdapat perbedaan fenotipik Anas platyrhynchos dan Cairina moschata. Warna bulu Entok dominan hitam dan putih, sedangkan pada itik muncul warna coklat. Warna paruh entok adalah merah muda dengan hitam kecoklatan, namun pada itik kebanyakan berwarna hitam. Baik itik maupun entok, warna shank yang dominan adalah hitam. Ukuran tubuh Entok lebih besar daripada Itik, serta bobot badan Itik Magelang lebih besar dari Itik Tegal dan Itik Mojosari. Hasil PCR-RFLP menunjukan nilai Heterozigositas itik lebih rendah daripada entok berdasarkan gen GH, selanjutnya jarak genetik Itik Tegal lebih dekat dengan itik Mojosari dan Magelang. Itik Magelang dan Mojosari memiliki jarak genetik yang cukup besar berdasarkan gen $\mathrm{GH}$.

Kata kunci: mallard, entok, GH Anas, GH Cairina, PCR-RFLP

\section{Introduction}

Native Indonesian ducks are germ plasm that requires preservation and improvement in genetic quality to increase farmers' income. Several types of native ducks have authentic morphological characteristics and are named in accordance to the location, such as Tegal duck, Magelang duck, Mojosari duck, Bali duck, and
Alabio duck in South Kalimantan (Ismoyowati and Purwantini, 2010). The ducks are presumably the crossbred of some native ducks with imported ducks and therefore result in various plumage colors and names (Yuwanta et al., 2001). The native ducks have a considerable genetic variation as reflected from the morphological characteristics and productivity. 
This condition, however, imposes difficulty to determine the strain of duck to be the superior breed because the domesticated ducks are derived from the unknown breed with particular genetic structure and ancestor.

Information on genetic attribute of particular species is significant for efficient conversion, characterization, improvement and utilization. This information can be accessed through the characteristics of biochemistry, immunology, molecular and morphology (Oguntunji and Ayorinde, 2014). Identification can focus on the phenotypic characteristics of both qualitative (color, plumage, skin, bill and webs) and quantitative by calculating body weight, production and egg quality. Phenotypic identification is needed to observe the tangible morphological characteristics among native ducks. Biomolecular identification can be performed to investigate genetic variation from the ducks.

Different methods of analyzing genetic variation using molecular DNA include RAPD (Randomly Amplified Polymorphic DNA), PCRRFLP (Restriction Fragment Length Polymorphism), fingerprinting, Minisatellite (VNTR/Variable number tandem repeats), Microsatelite (STR/restriction tandem repeats) and mtDNA (Herman, 2004; Sartika, 2007). Rojas et al. (2011) stated that PCR-RFLP method in mtDNA from fragment 125rRNA is applicable to various food products such as meat from different animals. RFLP has the lowest and most informative standard deviation and many advantages high consistency, codominant inheritance, being repeatable without changes and easy identification due to a different gap between fragments (Garcia et al., 2004). Knowledge of genetic variation of Indonesian native mallards and Muscovy is very important because it serves as consideration to conserve native ducks, provides opportunity in selecting and improving the genetic quality that eventually improves the economic value of native mallard and Muscovy.

The research was conducted to identify the extent of phenotypic diversity among native mallard and Muscovy on quantitative and qualitative basis and the extent of genetic diversity among native mallard and Muscovy based on RFLP method using primer gene growth hormone $(\mathrm{GH})$.

\section{Materials and Methods \\ Materials}

A total of 50 male and female ducks aged 30 weeks consisted of Magelang duck, Mojosari duck, Tegal duck, white-feathered and black and white-feathered Muscovy were administered in the study. The research was conducted for 5 months in ducks farming in Dukuhwaluh village, Kembaran, Banyumas. DNA isolation and PCRRFLP was conducted in the Integrated Research Laboratory, Jenderal Soedirman University. Chemicals used were ETDA as anticoagulant, DNA isolation kit, 2 primers, PCR core kit, DNA molecular weight, agarose, TBE solution, and endonuclease and ethidiumbromide enzymes. The apparatus consisted of writing pad and pen, digital scale, tape measure, digital balance scale, measuring cylinder, syringe, efendorf, sterile tube, centrifuge, PCR machine and horizontal electrophoresis. Microsatellite primers in the study were GH Cairina F, GH Cairina R, GH Anas $\mathrm{F}$, and $\mathrm{GH}$ Anas $\mathrm{R}$.

Completely Randomized Design (CRD) was used to analyze the quantitative characteristics (body morphology) of male Mojosari duck, female Mojosari duck, male Magelang duck, female Magelang duck, male Tegal duck, female Tegal duck, male white Muscovy, female white Muscovy, male black and white Muscovy and female black and white Muscovy.

\section{Research Design}

Analysis design of PCR-RFLP started with composing $25 \mu \mathrm{lPCR}$ solution that consisted of $12.5 \mu \mathrm{l} \mathrm{PCR}$ master mix, $1 \mu \mathrm{l}$ forward primer, $1 \mu \mathrm{l}$ reserve primer, $1 \mu \mathrm{l}$ DNA and $9.5 \mu \mathrm{l} \mathrm{H}_{2} \mathrm{O}$. PCR was performed using a thermocycler programed as follows: 5 -minute pre-denaturation at $94^{\circ} \mathrm{C}, 30$ second denaturation at $94^{\circ} \mathrm{C}, 45$-second annealing at $56^{\circ} \mathrm{C}$, and elongation at $72^{\circ} \mathrm{C}$ for one and five minutes. Amplification result was cut using Alu1 enzyme with a mixture or RFLP that consisted $7.7 \mu \mathrm{l}$ DDW, buffer $1.2 \mu \mathrm{l}$ Tango, $0.1 \mu \mathrm{l}$ restriction enzyme and $3 \mu \mathrm{l}$ PCR product. 
Firman Febrianto, et al. /Animal Production. 20(1):17-27, 2018

Accredited by Kemenristek Dikti No 32a/E/KPT/2017. ISSN 1411-2027

Table 1. Microsatellite primers

\begin{tabular}{cll}
\hline No & Primer & Sequence of nucleotide \\
\hline \multirow{2}{*}{1} & GH Cairina $\mathrm{F}$ & CTGGGGTTGTTTAGCTTGGA \\
& GH Cairina R & TAAACCTTCCCTGGCACAAC \\
\hline 2 & GH Anas $F$ & CTCTGGGCTGTTTCAGAAGG \\
& GH Anas R & AGGTATTGCACTGGGGTCAG \\
\hline
\end{tabular}

NCBI GH Cairina Genbank AB 158762.1, GH Anas Genbank AB 158760.2

Variables measured were (1) phenotypes of mallard and Muscovy that included quantitative characteristics such as body weight, bill length, bill width, neck length, neck diameter, back length, back width, girth, breast base, chest girth, wingspan, femur length, leg diameter, leg length, leg diameter, digit III length; and qualitative characteristics including the color of wing feather, plumage, tail, breast, crown, leg and bill, (2) genetic diversity as per the amount of alleles identified based on gen $\mathrm{GH}$, heterozygocity and genetic distance.

Qualitative characteristics (the color of wing feather, plumage, tail, chest, crown, bill and shank) were subject to descriptive analysis by counting the proportion (\%) of the observed feature. RFLP analysis was used to identify the allele frequencies, genotype frequencies, genetic diversity and genetic distance of local ducks. Each mallard strain was replicated five times, so the total water fowl used was 50 ducks with fixed factors of strain and sex. HSD test was performed on significant difference.

\section{Results and Discussion \\ Morphological Characteristics of Mallard and Muscovy}

The qualitative characteristics that included the color of wing feather, plumage, tail, chest, crown, bill and shank are presented in Table 2 (male) and Table 3 (female). The feather colors of male Tegal, Mojosari and Magelang ducks were highly varied, dominated by the combination of brown, black and gray. However, the feather color in Mojosari ducks was more greenish (Table 2).

Plumage color in 3 native female ducks (Tegal, Magelang, Mojosari) were similar from crown to tail. Tegal duck has light brown plumage, Magelang duck is spotted black and Mojosari duck is black and brown. The three native mallards had a dominant black bill and shank (Table 3). In contrast, male and female, white Muscovy had similar colors namely dominant white, while male and female black Muscovy had dominant black plumage with white spots. The two types of mallard had a pink bill with black spots and the shank was a combination of black and white.

Morphological characteristics in Tegal duck, Magelang duck, Mojosari duck, male white Muscovy and black Muscovy are presented in Table 4. Analysis result showed significant difference $\mathrm{Ha}(\mathrm{P}<0.05)$ on body weight, chest crease, neck diameter, leg diameter, shank diameter, bill width, back width, girth, the length of digiti III, bill length, back length, and shank length.

Morphological characteristics of Tegal duck, Magelang duck, Mojosari duck, and female white Muscovy and black Muscovy are presented in Table 5. The significant difference $(P<0.05)$ was in body weight, neck diameter, leg diameter, shank diameter, bill width, back width, girth, the length of digiti III and back length.

The result of HSD test to Tegal duck, Magelang duck, Mojosari duck, white Muscovy and black Muscovy showed significant difference in some morphological/phenotypic characteristics. White Muscovy (male and female) had superior morphometric characteristics to the other strains in terms of body weight, chest crease, neck diameter, leg, shank, back width, lingkar chest, the length of digiti III, and shank length. Mulyono and Pangestu (1996) stated that the physical diversity of fowl was attributed to different body shape and measure through morphometric measurement. Morphometric measurement could be utilized to identify the shape and size of cattle (Hayashi et al. 1982; Mulyono and Pangestu 1996; Ogah et al. 2009). 
Firman Febrianto, et al. /Animal Production. 20(1):17-27, 2018

Accredited by Kemenristek Dikti No 32a/E/KPT/2017. ISSN 1411-2027

Table 2. Qualitative characteristics of male Tegal, Magelang and Mojosari ducks, and white Muscovy and black Muscovy

\begin{tabular}{|c|c|c|c|c|c|c|}
\hline \multirow{2}{*}{ No } & \multirow{2}{*}{ Color } & \multicolumn{5}{|c|}{ Waterfowl } \\
\hline & & Tegal & Magelang & Mojosari & White Muscovy & Black Muscovy \\
\hline 1 & Wing & Brown & Brown, black, white & Gray with green stripes & White & Black and white \\
\hline 2 & Plumage & Brown & Black, brown & Gray & White & Black and white \\
\hline 3 & Tail & Black, brown & Brown, black, white & Black brownish & White & Black and white \\
\hline 4 & Breast & Brown & Brown & Gray & White & White \\
\hline 5 & Crown & Black, brown & Greenish black & Greenish black & White & Black and white \\
\hline 6 & Bill & Black & Black & Greenish black & Pink with black spots & Pink with black spots \\
\hline 7 & Shank & Brown & Black, orange & Orange, blackish & White with black spots & Black with white spots \\
\hline
\end{tabular}

Table 3. Qualitative characteristics of female Tegal, Magelang and Mojosari ducks, and white Muscovy and black Muscovy

\begin{tabular}{|c|c|c|c|c|c|c|}
\hline \multirow[t]{2}{*}{ No } & \multirow{2}{*}{$\begin{array}{l}\text { Color } \\
\text { feature }\end{array}$} & \multicolumn{5}{|c|}{ Waterfowl } \\
\hline & & Tegal & Magelang & Mojosari & White Muscovy & Black Muscovy \\
\hline 1 & $\begin{array}{l}\text { Wing } \\
\text { feather }\end{array}$ & Light brown & Black brownish & Black, brown & White & Black and white \\
\hline 2 & Plumage & Light brown & Black, brown & Black, brown & White & Black and white \\
\hline 3 & Tail & Light brown & Black, brown & Black, brown & White & Black and white \\
\hline 4 & Breast & Light brown & Black, brown & Black, brown & White & Black and white \\
\hline 5 & Crown & Light brown & Black with brown stripes & Black, brown & White with black spots & Black \\
\hline 6 & Bill & Black & Black & Greenish black, brown & Pink with black spots & Pink with black spots \\
\hline 7 & Shank & Black & Black brownish & Black, dark brown & White with black spots & Black \\
\hline
\end{tabular}

Table 4. Mean and Standard Deviation of Morphometric characteristics of Male Tegal, Magelang and Mojosari ducks, and white Muscovy and black Muscovy

\begin{tabular}{|c|c|c|c|c|c|c|}
\hline \multirow{2}{*}{ No } & \multirow{2}{*}{ Characteristics } & \multicolumn{5}{|c|}{ Waterfowl } \\
\hline & & Tegal & Magelang & Mojosari & White Muscovy & Black Muscovy \\
\hline 1 & Body weight (g) & $1430 \pm 44.72^{c}$ & $1710 \pm 134.16^{b}$ & $1570 \pm 97.47^{c}$ & $3320 \pm 115.11^{\mathrm{a}}$ & $3220 \pm 57.01^{a}$ \\
\hline 2 & Chest crest (mm) & $105 \pm 5^{c}$ & $109 \pm 6.52^{c}$ & $112 \pm 9.08^{b c}$ & $143 \pm 6.71^{\mathrm{a}}$ & $128 \pm 13.04^{\mathrm{ab}}$ \\
\hline 3 & Neck diameter (mm) & $75.2 \pm 1,30^{\mathrm{b}}$ & $78.8 \pm 2.39^{b}$ & $80.4 \pm 2.70^{b}$ & $106.2 \pm 7.08^{\mathrm{a}}$ & $98.6 \pm 6.46^{a}$ \\
\hline 4 & Leg diameter (mm) & $94.6 \pm 4,56^{c}$ & $120.2 \pm 10.06^{b}$ & $115.2 \pm 6.14^{b}$ & $151 \pm 7.87^{a}$ & $167 \pm 15.80^{\mathrm{a}}$ \\
\hline 5 & Shank diameter (mm) & $97 \pm 4.24^{d}$ & $114.2 \pm 6.76^{c}$ & $110.4 \pm 2.30^{c}$ & $143.2 \pm 4.21^{\mathrm{b}}$ & $157.4 \pm 7.20^{\mathrm{a}}$ \\
\hline 6 & Bill width (mm) & $40.8 \pm 0,84^{b}$ & $46.8 \pm 1.64^{a}$ & $44.4 \pm 1.52^{\mathrm{ab}}$ & $42.2 \pm 2.28^{b}$ & $43.4 \pm 3.44^{\mathrm{ab}}$ \\
\hline 7 & Back width (mm) & $98 \pm 7.58^{b}$ & $102 \pm 5.70^{b}$ & $104 \pm 11.40^{b}$ & $141 \pm 5.48^{\mathrm{a}}$ & $143 \pm 6.70^{\mathrm{a}}$ \\
\hline 8 & Girth (mm) & $290 \pm 7,07^{b}$ & $294 \pm 8,94^{b}$ & $294 \pm 5,48^{b}$ & $382 \pm 8,37^{a}$ & $380 \pm 7,07^{a}$ \\
\hline 9 & Femur length (mm) & $82 \pm 2.74$ & $84 \pm 5.48$ & $81 \pm 2.24$ & $106 \pm 4.18$ & $99 \pm 4.18$ \\
\hline 10 & Humerus length (mm) & $92 \pm 5,70$ & $121 \pm 5,48$ & $100 \pm 3,54$ & $131,4 \pm 7,40$ & $132 \pm 13,04$ \\
\hline 11 & Digiti III length (mm) & $51.6 \pm 1.81^{b}$ & $52.2 \pm 2.28^{b}$ & $55 \pm 5.0^{b}$ & $71.8 \pm 2.49^{a}$ & $74.8 \pm 3.11^{\mathrm{a}}$ \\
\hline 12 & Neck length (mm) & $215 \pm 5.0$ & $228.4 \pm 7.92$ & $215 \pm 21.79$ & $214.4 \pm 6.27$ & $211.4 \pm 5.46$ \\
\hline 13 & Bill length (mm) & $59 \pm 1.41^{b}$ & $68.2 \pm 1.48^{a}$ & $69.2 \pm 2.95^{\mathrm{ab}}$ & $66.6 \pm 2.79^{b}$ & $62.8 \pm 1.64^{\mathrm{ab}}$ \\
\hline 14 & Back length (mm) & $190 \pm 6.12^{b}$ & $200 \pm 10.0^{b}$ & $204 \pm 18.16^{b}$ & $306 \pm 18.16^{a}$ & $285.8 \pm 20.70^{a}$ \\
\hline 15 & Shank length (mm) & $61 \pm 2.65^{b}$ & $63.6 \pm 1.95^{b}$ & $63.2 \pm 4.44^{b}$ & $71.6 \pm 4.77^{a}$ & $73.6 \pm 5.90^{\mathrm{a}}$ \\
\hline 16 & Tibia length (mm) & $99 \pm 4.18$ & $106 \pm 4.18$ & $108 \pm 8.37$ & $122 \pm 5.70$ & $127 \pm 4.47$ \\
\hline 17 & Ulna length (mm) & $91 \pm 4.18$ & $105 \pm 3.54$ & $99 \pm 7.42$ & $131.4 \pm 7.0$ & $132 \pm 13.04$ \\
\hline
\end{tabular}

Note: Values bearing different superscript within row show significant difference based on HSD at 5\%. 
Firman Febrianto, et al. /Animal Production. 20(1):17-27, 2018

Accredited by Kemenristek Dikti No 32a/E/KPT/2017. ISSN 1411-2027

Table 5. Mean and standard deviation of morphometric characteristics in Female Tegal, Magelang and Mojosari ducks, and white Muscovy and black Muscovy

\begin{tabular}{|c|c|c|c|c|c|c|}
\hline \multirow{2}{*}{ No } & \multirow{2}{*}{ Characteristics } & \multicolumn{5}{|c|}{ Waterfowl } \\
\hline & & \multirow{2}{*}{$\begin{array}{c}\text { Tegal } \\
1440 \pm 221.9^{b}\end{array}$} & \multirow{2}{*}{$\begin{array}{c}\text { Magelang } \\
1690 \pm 74.2^{\mathrm{ab}}\end{array}$} & \multirow{2}{*}{$\begin{array}{c}\text { Mojosari } \\
1400 \pm 79.1^{\mathrm{b}}\end{array}$} & \multicolumn{2}{|c|}{ White Muscovy Black Muscovy } \\
\hline & Body weight (g) & & & & $2160 \pm 462.9^{a}$ & $2090 \pm 198.1^{\mathrm{a}}$ \\
\hline & Chest crease (mm) & $102.8 \pm 6.8$ & $102 \pm 4.5$ & $105 \pm 5.0$ & $97.6 \pm 11.9$ & $100.4 \pm 3.6$ \\
\hline & Neck diameter (mm) & $71.6 \pm 2.3^{b}$ & $75 \pm 5.1^{b}$ & $74.8 \pm 3.8^{b}$ & $86.2 \pm 6.7^{a}$ & $80.6 \pm 8.4^{a}$ \\
\hline & Leg diameter (mm) & $111.2 \pm 17.1^{\mathrm{ab}}$ & $128.6 \pm 9.1^{\mathrm{a}}$ & $97.6 \pm 2.5^{b}$ & $120.8 \pm 8.6^{a}$ & $114 \pm 4.2^{\mathrm{ab}}$ \\
\hline & Shank diameter (mm) & $106.2 \pm 4.8^{c}$ & $116.8 \pm 4.4^{\mathrm{b}}$ & $98.2 \pm 2.5^{c}$ & $128.8 \pm 8.3^{\mathrm{a}}$ & $123.6 \pm 4.4^{\mathrm{ab}}$ \\
\hline & Bill width $(\mathrm{mm})$ & $44.6 \pm 2.9^{a}$ & $42 \pm 2.5^{\mathrm{ab}}$ & $40.6 \pm 1.8^{\mathrm{ab}}$ & $39 \pm 4.1^{b}$ & $40 \pm 1.6^{\mathrm{ab}}$ \\
\hline & $\begin{array}{l}\text { Back width } \\
(\mathrm{mm})\end{array}$ & $88 \pm 8.4^{c}$ & $106 \pm 6.5^{\mathrm{ab}}$ & $99 \pm 4.2^{\mathrm{bc}}$ & $117.2 \pm 6.8^{\mathrm{a}}$ & $114.6 \pm 4.6^{\mathrm{a}}$ \\
\hline & Girth (mm) & $261 \pm 19.8^{c}$ & $299 \pm 7.4^{\mathrm{ab}}$ & $282 \pm 7.6^{\text {bc }}$ & $320 \pm 13.7^{a}$ & $309 \pm 7.4^{a}$ \\
\hline & Femur length (mm) & $74 \pm 5.5$ & $75 \pm 3.5$ & $76 \pm 4.2$ & $83.2 \pm 7.2$ & $77 \pm 5.7$ \\
\hline & Humerus length $(\mathrm{mm})$ & $99 \pm 2.2$ & $94 \pm 4.2$ & $91 \pm 2.2$ & $113.8 \pm 9.4$ & $115 \pm 13.2$ \\
\hline & Digiti III length (mm) & $52 \pm 4.5^{b}$ & $56.4 \pm 4.4^{b}$ & $55,8 \pm 3.8^{b}$ & $67.4 \pm 9.5^{a}$ & $56.8 \pm 3.3^{b}$ \\
\hline & Neck length (mm) & $200 \pm 7.1$ & $198 \pm 13.0$ & $180 \pm 7.1$ & $180 \pm 23.4$ & $182 \pm 13.0$ \\
\hline & Bill length (mm) & $62.4 \pm 2.5$ & $61 \pm 1.6$ & $60 \pm 1.6$ & $59.2 \pm 3.9$ & $58.4 \pm 2.1$ \\
\hline & Back length $(\mathrm{mm})$ & $198 \pm 22.5^{b}$ & $207 \pm 6.7^{b}$ & $196 \pm 9.6^{b}$ & $258.6 \pm 25.8^{a}$ & $251.2 \pm 9.5^{\mathrm{a}}$ \\
\hline & Shank length (mm) & $60.6 \pm 2.6$ & $58.4 \pm 2.3$ & $54,6 \pm 4.6$ & $58.2 \pm 3.0$ & $56.2 \pm 3.9$ \\
\hline & Tibia length $(\mathrm{mm})$ & $102 \pm 4.5$ & $104 \pm 5.5$ & $92 \pm 5.7$ & 105.8 & $102 \pm 5.7$ \\
\hline & Ulna length (mm) & $90 \pm 1.0$ & $96 \pm 4.2$ & $82 \pm 2.7$ & $113 \pm 10.8$ & $110 \pm 7.9$ \\
\hline
\end{tabular}

Note: Values bearing different superscript within row show significant difference based on HSD at $5 \%$.

Quantitative characteristics of Magelang duck were higher than those of other native mallards. Ismoyowati and Purwantini (2009) reported that Magelang duck had higher body weight than that of Tegal duck and Mojosari duck, namely $1734 \mathrm{~g}$ compared to $1482 \mathrm{~g}$ and $1476 \mathrm{~g}$, respectively. A fast growth rate in male ducks was due to androgen hormone. Androgen hormone in some animals stimulated protein anabolism and increased nitrogen retention (Meisji et al, 2012), played a role in bone growth, increased the amount and the thickness of muscle fibers, and improved the muscle resistance and performance. Meat in the chest can be used to evaluate meat distribution in other body parts (Parkhust et al, 1997).

Different body measurement was due to genetic factor, environmental factor and feed. In general, mallard has a different morphology compared to the other fowls. Mallard has relatively shorter legs with webs between three digits that enable mallard to swim. The important qualitative characteristics to identify duck's morphology are thigh length, calves, tarsometatarsus, tarsometatarsus circumference, the length of digiti III, wings and bill (Mansjoer et al. 1989). The length of calves and tarsometatarsus can be used to estimate body conformity (Nishida et al. 1982) and has the most dominant correlation with body weight (Mansjoer et al. 1989). The length of tarsometatarsus is the best estimator for body weight due to the detailed measurement compared to calf length (Nishida et al. 1982).

Bone measurement was conducted with each strain of duck such as neck length, back length, back width and the length of digit III, where the bone measurement was correlated with body weight. Suparyanto (2005) stated that body shape was consisted of the dimension and body weight. Using body shape as measurement required additional consideration such as the proportion of a particular body part, which, according to farmers' experience would predict a good production feature in the next breeding.

Based on the result, bone size affected the body size of each mallard and Muscovy. Brahmantiyo et al. (2003) stated that ducks' 
Firman Febrianto, et al. /Animal Production. 20(1):17-27, 2018

Accredited by Kemenristek Dikti No 32a/E/KPT/2017. ISSN 1411-2027

body conformity would be more accurate when each bone measurement was conducted as the relation clue between one bone and the others. The bone length measurement was more accurate than body weight. Body measurement that determined the characteristics of fowl were body weight, the length of leg parts, wingspan, bill and comb height (Mansjoer et al. 1989).

The result showed that body weight and back width of Muscovy was higher than those of mallard; therefore, Muscovy body was bigger than mallard's. Muscovy ducks had the ability to efficiently process feed which was expressed in high protein content in leg meat and low-fat chest meat and skin. It was because Muscovy was a meat-source waterfowl while mallard is layer waterfowl that was bred for meat source; accordingly, the ability to produce meat was different between Muscovy and mallard according to body size.

The result showed a tangible qualitative difference in the crown and tail colors among the 5 strains of mallards. Plumage feather of male Tegal, Mojosari, and Magelang ducks was highly varied with the prevalent combination was brown, black and gray, but Mojosari duck had a greenish black color. Plumage color of the female Tegal, Magelang and Mojosari ducks was different from the male. Tegal duck had light brown plumage from crown to tail, Magelang duck was spotted black while Mojosari duck had the black and brown combination. The similar characteristics among the three ducks were the bill and shank dominated with black color.

In contrast to native mallard, it was difficult to tell the sex of Muscovy based on plumage color, bill and shank because the features were similar from male to female. Male and female white muscovy, had typical dominant white plumage, while the plumage of male and female combination feather color was dominantly in black with white spots. The two types of Muscovy had a pink bill with black spots and shank with black and white color. According to Bati et al. (2014), Muscovy had many strains with various colors such as black, black and white, sepia and brown. Black plumage Muscovy was the broadest source of genetic.
Quantitative phenotypic characteristics in Muscovy (Cairina moschata) and mallard (Anas platyrhynchas) were significantly different. Among different morphological characteristics, body weight was the most significant compared to neck length, chest crease, ulna length, back width, shank diameter back length, femur length, humerus length, tibia length, leg diameter, neck diameter and girth. Body weight of male Muscovy was higher than that of female Muscovy. According to Steczny et al. (2017), sex affected body weight of 6 -week old mallard. The increased body weight gap between male and female mallard from 35 to 49 days old would indicate a more intensive growth in male than female at a later age. Androgenic hormones of male mallards offered with similar feed composition improve protein metabolism and growth rate of skeletal muscle.

In general, morphological characteristics of male Tegal duck, Magelang duck, Mojosari duck, white Muscovy and black Muscovy were higher than those of female ducks. Baeza et al. (2001) stated that sex affected growth hormones. It was in line with Lelercq and de Carville (1997) who reported $3950 \mathrm{~g}$ mean body weight of male Muscovy, almost double the female Muscovy (2006 g). Boody size of Muscovy was larger than that of mallard. According to Jaohari et al. (2013), chest length and girth were the distinguish morphology variables between mallard, Muscovy and female mule duck.

Result of morphological characteristics analysis showed different phenotype size. The similar phenotype as per body size in male and female mallard and male and female Muscovy indicated the diversity among the strains that could be affected by genetic and environmental factors, and mutation, either natural or modified (Brahmantiyo et al., 2003).

\section{Genetic diversity in Anas Platyrhynchos and Cairina moschata}

Genetic diversity can be harnessed to improve productivity and uniformity of mallard (Prasetyo 2006). Genetic diversity is significant to identify the family (Susanti and Prasetyo 2009). The diversity was owing to different 
Firman Febrianto, et al. /Animal Production. 20(1):17-27, 2018

Accredited by Kemenristek Dikti No 32a/E/KPT/2017. ISSN 1411-2027

farming maintenance and feeding (Suryana, 2011), and breeding system that was not in accordance to a controlled breeding program (Prasetyo 2006).

Genetic diversity in Anas Platyrhynchos and Cairina moschata in this study was measured by analyzing Deoxyribo Nucleic Acid (DNA) where the total genome was extracted from blood samples and isolated using DNA isolation Kit (Geneaid) then analyzed using PCR-RFLP, continued by slicing the particular sequence using Alu I enzyme. The detection was aimed to investigate the polymorphism in mallard and Muscovy. PCR-RFLP analysis was successful to identify the genetic diversity of Magelang duck and other native mallards (Purwantini et al., 2013). The result of PCR-RFLP electrophoresis in an area cut by Alu I enzyme in Tegal duck and the other native mallards using $\mathrm{p}$ primer $\mathrm{GH}$ Anas is presented in Figure 1.

The Result data were obtained from the occurrence of microsatellite DNA ribbon from PCR (Polymerase Chain Reaction) result in the population of Tegal duck, Magelang duck, Mojosari duck, white Muscovy and black Muscovy (Table 6 and 7). Microsatellites marker was polymorphic, indicating a viability for genetic diversity and phylogenetic mallard analysis (Veeramani et al, 2014).

The allele frequency scores in the table 6 and 7 were used to calculate estimation heterozygosity value. Table 8 shows a variation in heterozygosity score of each allele in the different gene of Tegal duck, Magelang duck,

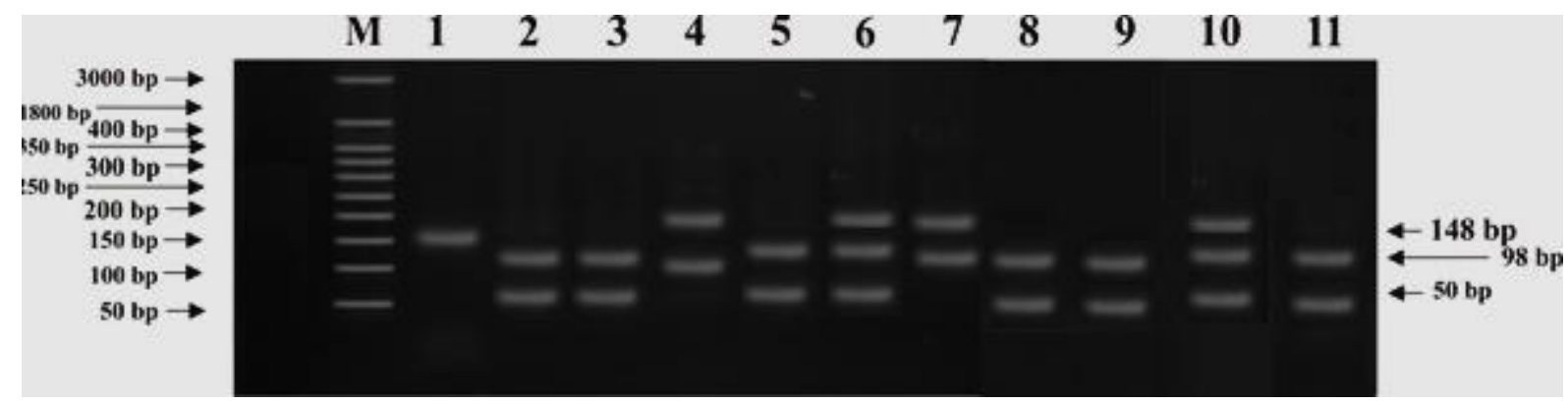

Figure 1. Result of GH Anas PCR-RFLP electrophoresis in an area cut by Alu I enzyme in mallard and Muscovy

Note: (M) marker DNA, (1) PCR product, (2 \& 3) Mojosari duck, (4 \& 5j) Black Muscovy, (6 \& 7) White Muscovy, (8 \& 9) Tegal duck, (10 \& 11) Magelang duck

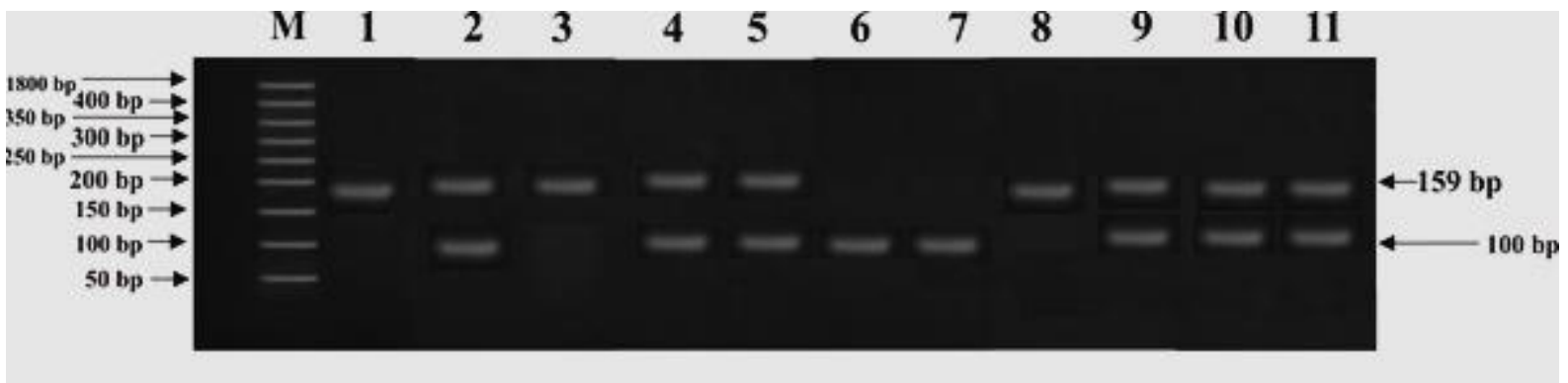

Figure 2. Result of GH Cairina PCR-RFLP electrophoresis in an area cut by Alu I enzyme in Tegal duck and other native mallards

Note: (M) marker DNA, (1) PCR product, (2 \& 3) white Muscovy (4 \& 5) Mojosari duck, (6 \& 7) black Muscovy, (8 \& 9) Tegal duck, (10 \& 11) Magelang duck. 
Table 6. Frequency alel Tegal duck, Magelang duck, Mojosari duck, white Muscovy and black Muscovy yang dengan Primer GH Anas

\begin{tabular}{ccccccccc}
\hline \multirow{2}{*}{ No } & \multirow{2}{*}{ Restriction Site } & \multicolumn{5}{c}{ Waterfowl } & \multirow{2}{*}{ Amount } & \multirow{2}{*}{ Frequency } \\
\cline { 3 - 6 } & & $\mathrm{T}$ & $\mathrm{MG}$ & $\mathrm{M}$ & $\mathrm{EP}$ & $\mathrm{EH}$ & & \\
\hline 1 & $50 \mathrm{bp}$ & 0.47 & 0.36 & 0.28 & 0.35 & 0.36 & 1.82 & 0.36 \\
2 & $98 \mathrm{bp}$ & 0.53 & 0.46 & 0.40 & 0.40 & 0.43 & 2.21 & 0.44 \\
3 & $148 \mathrm{bp}$ & 0 & 0.18 & 0.32 & 0.25 & 0.21 & 0.97 & 0.20 \\
\hline
\end{tabular}

Table 7. The allele frequency of Tegal duck, Magelang duck, Mojosari duck, white Muscovy and black Muscovy used primer GH Cairina

\begin{tabular}{|c|c|c|c|c|c|c|c|c|}
\hline \multirow{2}{*}{ No } & \multirow{2}{*}{ Restriction Site } & \multicolumn{5}{|c|}{ Waterfowl } & \multirow{2}{*}{ Amount } & \multirow{2}{*}{ Frequency } \\
\hline & & $T$ & MG & $M$ & EP & $\mathrm{EH}$ & & \\
\hline 1 & 20 & 0 & 0 & 0 & 0 & 0 & 0 & 0.00 \\
\hline 2 & 139 & 0.41 & 0.29 & 0.47 & 0.47 & 0.17 & 1.81 & 0.36 \\
\hline 3 & 159 & 0.59 & 0.71 & 0.53 & 0.53 & 0.83 & 3.19 & 0.64 \\
\hline
\end{tabular}

Table 8. Estimation heterozygosity per locus $(\mathrm{He})$ in the population of Tegal duck, Magelang duck, Mojosari duck, white Muscovy and black Muscovy based on GH Cairina and GH Anas gene.

\begin{tabular}{lcc}
\hline \multirow{2}{*}{ Locus } & \multicolumn{2}{c}{ Expected heterozygosity } \\
\cline { 2 - 3 } & GH Cairina & GH Anas \\
\hline Tegal & $0.484 \pm 0.159$ & $0.499 \pm 0.150$ \\
Magelang & $0.408 \pm 0.194$ & $0.628 \pm 0.106$ \\
Mojosari & $0.499 \pm 0.150$ & $0.659 \pm 0.089$ \\
White Muscovy & $0.499 \pm 0.150$ & $0.655 \pm 0.096$ \\
Black Muscovy & $0.278 \pm 0.246$ & $0.643 \pm 0.124$ \\
\hline
\end{tabular}

Mojosari duck, white Muscovy and black Muscovy. Heterozygosity score showed that genetic diversity in the population of mallard and Muscovy was medium (he $=0.278-0.499$ ), quite different from that in white Muscovy and black Muscovy namely $0.278 \pm 0.246$ and $0.499 \pm 0.150$, respectively. Heterozygosity score between Mojosari duck and Tegal duck was not significantly different $0.484 \pm 0.159$ and $0.499 \pm 0.150$, respectively, while $h$ score in mallard population was significantly different from that of Muscovy. It indicated a high genetic diversity between a mallard and Muscovy. Mulliadi and Ariin (2010) stated that the changed gene frequencies in the observed DNA area played a role in yielding heterozygosity score. Therefore, mallards in this study had a close genetic relation. There were a great variation in estimation of heterozygosity (He) values in various duck populations, i.e., 0.509; 0.695 and 0.728 each of duck populations from Mojosari, Tegal and Magelang, based on microsatellite (Ismoyowati and Purwantini, 2010).

Genetic distance is the gene interval between populations or species measured on numeric scores and calculated on genetic frequencies in subpopulation. Table 9 shows a considerable genetic distance in mallard and Muscovy; therefore, the changing gene frequencies were small, so there was no significant increase in $h$ score. A genetic distance of $\mathrm{GH}$ Anas is presented in the summary of the genetic distance analysis of Tegal duck, Magelang duck, Mojosari duck, white Muscovy and black Muscovy in Table 10. 
Based on RFLP gen GH analysis, the genetic distance between Tegal duck and Magelang was 0.063 (Table 14) within the range of $0.009-$ 0.691 (Purwantini et al. 2013), quite an opposite to 0.169 reported by Hendrik et al. (2016). The different genetic distance was presumably due to a different gene, method and analysis technique. The result indicated that mallard had a considerably close distance. The genetic distance between Muscovy and mule duck was closer (3.97) compared to mallard and mule duck (14.10) and Muscovy with mallard (24.73). Fatmarischa et al (2014) reported that differences from distribution mapping between male and female of Muscovy with stepwise analysis obtained the discriminant variables of male Muscovy measurement existed on breast circumference (0.85) and neck length (0.66), meanwhile for female Muscovy on femur length (0.68) and bill length (0.82).

Genetic distance is the rate of gene diversity (genomic difference) of a population or species measured on numeric quantity (Nei, 1978). The result of genetic distance based on body measurements showed that Tegal duck had a considerable or medium distance with Magelang duck, Mojosari duck, white Muscovy and black Muscovy. Beside a distant genotype with Tegal duck, Magelang duck also had distant genotype with Mojosari duck, white Muscovy and black Muscovy Mojosari duck, white Muscovy and black Muscovy. Similarly, the white Mojosari duck had a quite distant genotype with black Muscovy. Muscovy duck was genetically different from mallards. It was in accordance with Hoffman (2001) that Muscovy (Cairina moschata) was genetically different from mallard (Anas platyrhynchas). Furthermore, Crawford (1990) stated that the amount of chromosomes in Muscovy and mallard was 80 consisted of the 39 body chromosomes and a pair of sex chromosome. However, there was still a close relation between a mallard and Muscovy.

The result of this study was in line with that of Fatmarischa, Sutopo and Johari (2014) where a genetic relation was found between male and female Muscovy with Muscovy in Magelang and Pekalongan, but distant genetic relation with Demak Muscovy. According to El-Gendy et al.

Table 9. Genetic distance between Tegal duck, Magelang duck, Mojosari duck, white Muscovy and black Muscovy GH Cairina

\begin{tabular}{lcccc}
\hline \multicolumn{1}{c}{ Waterfowl } & Magelang & Mojosari & White Muscovy & Black Muscovy \\
\hline Tegal & 0.045 & 0.008 & 0.008 & 0.143 \\
Magelang & & 0.042 & 0.042 & 0.154 \\
Mojosari & & & 0.001 & 0.149 \\
White Muscovy & & & 0.149 \\
Black Muscovy & & & \\
\hline
\end{tabular}

Table 10. Genetic distance between Tegal duck, Magelang duck, Mojosari duck, white Muscovy and black Muscovy GH Anas

\begin{tabular}{lcccc}
\hline \multicolumn{1}{c}{ Waterfowl } & Magelang & Mojosari & White Muscovy & Black Muscovy \\
\hline Tegal & 0.063 & 0.079 & 0.080 & 0.067 \\
Magelang & & 0.147 & 0.144 & 0.126 \\
Mojosari & & & 0.161 & 0.138 \\
White Muscovy & & & 0.147 \\
Black Muscovy & & & \\
\hline
\end{tabular}


(2005), close genetic relation was due to specific genetic composition to interaction in environmental condition.

\section{Conclusions}

There were phenotypic differences between Anas Platyrhynchos and Cairina moschata in both qualitative and quantitative basis. The tangible differences were on plumage colors, bill color, shank color, body size, and body weight. Muscovy had dominant black and white plumage, pink bill with black spots, black shank, bigger body than a mallard, and body weight of Magelang duck was higher than that of Tegal and Mojosari ducks. Mallard had dominant brown plumage, black bill, and dominant black shank. The genetic diversity was identified between Anas Platyrhynchos and Cairina moschata from RFLP analysis using gene growth hormone (GH), where heterozygosity of mallard was higher than that of Muscovy.

\section{References}

Baeza, E, Dessay C, Wacrenier N, Marche. G and Listrat A, 2002. Effect of Selection for Improved Body Weight and Composition on Muscle and Meat Characteristics in Muscovy Duck. Br Poult Sci. 43 (4): 560-568.

Bati, J. B., Biza Koukaba C. K., Banga-Mboko H., Mfoukou Ntsakala A., Bakoutana D., Adzona P. P., Hornick J. L. and P. L. Leroy. 2014. Phenotypic Characterization According to The Feather Color of Indigenous Muscovy Ducks Bred in The Back Yard in Brazzaville, The Congo. Animal Production. 16 (3): 140-145.

Brahmantiyo, B. L. H. Prasetyo, A. R. Setioko \& R H. Mulyono. 2003. Estimation of genetic distance and variables of Mallard strains (Alabio, Bali, Khaki Campbell, Mojosari and Pegagan) through Morphometric analysis. Jumal IImu Temak and Veteriner Badan Penelilian and Pengembangan Pertanian, Depanemen Pertanian. 8 (1): I-7.

Crawford, R. D. 1990. Poultry Breeding and Genetics. Eselvier, Amsterdam.

El-Gendy, EA. MA. Helal, NH. Goher and A. Mostageer. 2005 Molecular characterization of genetic biodiversity in ducks, using RAPD-PCR analysis. Arab J. Biotech., 8 (2): 253-264.

Fatmarischa, Sutopo and Johari. 2014. Genetic distance and variables of male and female
Muscovy through Morphometric Analysis. Jurnal Peternakan Indonesia. 16 (1): 33-39.

Garcia, A. A. F., Luciana L. Benchimol, Antonia M. M. Barbosa, Isaias O. Geraldi, Claudio L. Souza Jr. and Anete P. de Souza. 2004. Comparison of RAPD, RFLP, AFLP and SSR Markers for Diversity Studies in Tropical Maize Inbred Lines. Genetics and Molecular Biology. 27 (4): 579-588

Hayashi, Y., J. Otsuka, T. Nishida, and H. Martojo. 1982. Multivariate Craniometrics of Wild Banteng, Bos banteng and Five Traits of Native Cattle in Eastern Asia. in The Origin and Phylogeny of Indonesian Native Livestock Investigation on the Cattle Form and Their Wild Forms III: 19-30.

Herman, L. 2004. Species Identification in Poultry Eggs Products. Poultry Science. 83: 2083-2085.

Hoffman, HNS, 2001, Mule Duck. http://www. Cyborganik.com/People/Feathersite/

Poultry/Duck/Musc/Mule.html.

Ismoyowati and Dattadewi Purwantini. 2010. An Estimation of Genetic Variation in Indonesian Local Duck using Microsatellite Marker. Asian Journal of Poultry Science, 4: 198-204.

Ismoyowati, I Suswoyo, ATA Sudewo and SA Santosa. 2009. Increasing Productivity of Egg Production through Individual Selection on Tegal Ducks (Anas javanicus). Animal Production, 11 (3): 183188.Johari, S., N. D. Kusumandi and E. Kurnianto. 2013. Multivariate Analysis of the Morphological Traits of Female Duck, Muscovy-Duck and MuleDuck. J. Indonesian Trop. Anim. Agric. 38 (3): 143148.

Mansjoer, S. S. 1989. Evaluation of Production Characteristics of native chicken and the crossbreed with Rhode Island chicken. Dissertation. Graduate school Faculty of Agriculture Bogor.

Mulliadi, D. and J. Arifin. 2010. Estimation of population balance and heterozygosity using blood albumin protein blood pattern of Javanese Thin Tailed population in Indramayu. Jurnal IImu Ternak. 10 (2): 65-72.

Mulyono, R. H. and R. B. Pangestu. 1996. Statistical analysis of body measures and external genetic characteristics of native chicken, Pelung chicken and Kedu chicken. Review 1995/1996. Animal Science Faculty, Bogor.

Nei, M. 1978. Estimation of Average Heterozigosity and Genetic Distance from Small Number of Individual. Genetic. 39: 583-590.

Nishida, T., Y. Hayashi, T. Hashiguchi, and S. S. Mansjoer. 1982. Distribution and identification of Jungle Fowl in Indonesia. The Origin and Phylogeny of Indonesia Native Livestock. Report by The Research Group of Overseas Scientific Survey Part III: 85-89. 
Firman Febrianto, et al. /Animal Production. 20(1):17-27, 2018

Accredited by Kemenristek Dikti No 32a/E/KPT/2017. ISSN 1411-2027

Ogah, D. M., A. A. Alaga, and M. O. Momoh. 2009. Principal Component Factor Analysis of the Morphostructural Traits of Muscovy Duck. Intl. J. Poult. Sci. 8 (11): 1104-1108.

Oguntunji, A. O. and K. L. Ayorinde. 2014. Multivariate Analysis of Morphological Traits of the Nigerian Muscovy Ducks (Cairina moschata). Arch. Zootec. 63 (243): 483-493.

Prasetyo, L. H. 2006. Strategy and Opportunity of Mallard Breeding. Wartazoa. 16 (3): 109-115.

Purwantini, D., Ismoyowati, Prayitno, and S.S. Singgih. 2002. Polymorphism Blood Protein as Indicator for Production Characteristics of Indigenous Java Duck. Proceeding of International Seminar and Conference on "Technology and Policy of Indonesia Resources utilization", September 2022, Hamburg. Germany. P 32-37.

Rojas. M., I. Gonzales, M.A. Pavon, N. Pegels, P.E. Hernandes, T. Garcia and. R. Martin. 2011. Mitochondrial and Nuclear Markers for the Authentication of Partridge Meat and the Spesific Identification of Red-Legged Partridge Meat Products by Polymerase Chain Reaction. Poultry Science. 90: 211-222.

Sartika, T. 2007. Breeding and improvement of native chicken genetics. Taxonomy and history of chicken domestication. Biodiversity of native chicken in Indonesia: Benefit and potential. LIPI Press. Jakarta, Pp: 105-125.
Srigandono, B. 1992. Water fowl production. $3^{\text {rd }}$ Ed. Gadjah Mada University Press. Yogyakarta.

Steczny, K., D. Kokoszynski, Z. Bernacki, R. Wasilewski \& M. Saleh. 2017. Growth Performance, Body Measurements, Carcass Composition and Some Internal Organ Characteristics in Young Pekin Ducks. South African Journal of Animal Science. 47 (3): 399-406.

Suryana. 2011. Phenotypic and genetic characteristics of Alabio ducks and the integrated utiliation in South Kalimantan. Dissertation. Graduate school. Faculty of Agriculture Bogor.

Susanti, T. and L. H. Prasetyo. 2009. Estimation of genetic parameters of egg production characteristics of Alabio duck. In: Proceeding National Seminar of Animal Science Technology and Veterinary Pp. 588-610. 11-12 November 2008. Pusat Penelitian and Pengembangan Peternakan, Bogor.

Veeramani, P., R. Prabakaran, S. N. Sivaselvam, T. Sivakumar, S. T. Selvan and S. M. K. Karthickeyan. 2014. Analysis of Genetic Distance for Indigenous and Exotic Duck Breeds. Journal of Poultry Science and Technology. 2 (4): 84-86.

Yuwanta, Zusprizal Tri, A. Musofie and N.K. Warandi. 2001. Production and reproduction of Bantul ducks under different sex ratio, communal time and breeding system. Diponegoro University, Semarang, Pp. 68-78. 